\title{
Tibuana
}

\section{APPLICATION of MANUFACTURING SYSTEMS TO CALCULATE PRODUCTION TARGET NEEDS PRIDE CHAIR DESIGN}

\author{
Imron Rosyadi N.R., ${ }^{1}$, Matsaini $^{2}$ \\ ${ }^{12}$ Industrial Engineering Department ${ }^{1}$, Engineering Faculty, Madura University \\ Email: imron.rosyadi@unira.ac.id
}

\begin{abstract}
A process in a company or industry will never be separated from the name of the production, production is an important part of the running of a company or industry. This research aims to provide input to the company to be able to calculate the need for future production targets based on previous production data so that the company can prepare all production needs. Production can also be interpreted as an activity to increase the use of goods and benefits in fulfilling daily activities. In practice, a person or business entity that carries out production activities is called a producer. Producers produce goods to be sold to meet the needs of others and theirindividuals. Production activities, there is an activity of processing raw materials into semi-finished materials, and then proceeding from semi-finished materials to finished materials. Therefore, a separate focus is needed to determine the amount of production, output, and input that is done. One thing that can be done is knowing up to calculating the needs of all processes to the production target. While the focus of production activities from the production system to inventory is First, forecasting is important and foremost. Second, inventory control is very important in the production system for inventory, especially in planning the purchase and delivery of raw materials and components. Third, the production of large quantities of inventory items is more structured.
\end{abstract}

Keywords: Production, Target needs, Company

\section{INTRODUCTION}

Chairs have a function as seats, chairs should be designed as attractive as possible so that they can attract consumer interest. Such as a folding chair to be easily moved and requires little space when the folding chair is not in use. according to Chun-Tung et al 2012, explaining that based on their structure, folding chairs can be divided into 2 types, namely folding chairs and tables without tables. Each type of folding chair has different benefits and uses according to its design to meet consumer needs.Therefore, the folding chair designer needs to know the aspects that suit the consumer's wishes.

The new concept of an automatic chair that will be developed here is a combination of a chair and a table that can change automaticallyso that when not in use it can be stored without taking up space and still retains its beauty (Wignjosoebroto, 2003) explains thatergonomy aspects, work design system, and multifunction. The purpose of this research is to design an automatic lounge chair by taking into account the capacity and prioritizing ergonomics and comfort.

Product design and development are all processes related to the existence of a product which includes all activities from identifying customer desires to production, sales, and product delivery (Widodo, 2003).

A manufacturing system is a system that utilizes an industrial engineering approach to improve the quality, productivity, and efficiency of an integrated system consisting of people, equipment, materials, energy, and information through the process of designing, planning, operating, controlling, maintaining, and repairing by maintaining harmony. human aspects and the work environment (Wignjosoebro, 2006). Furthermore, an analysis will be carried out on several things including the calculation of production target requirements.

\section{METHODOLOGY}

In calculating the production target requirement, the first step that must be taken is to create a defect rate table. The defect rate 


\section{Tibuana}

Journal of applied Industrial Engineering-University of PGRI Adi Buana

DOI : https://doi.org/10.36456/tibuana.4.01.3173.23-27

p-ISSN 2622-2027

$e$-ISSN 2622-2035

table is obtained by recording production obtained is processed to find the average. In this study, we used production failure data at the work station for making chairs, includingtable manufacture, front seat manufacture, machine box manufacture, rear seat assembly, assembly, and automation. failures in each work station. Then the data To determine the amount of market demand, demand historical data for several years is needed. Furthermore, calculating the production requirements per year using the formula:

\section{KPH= Demand $+\Sigma($ DemandxDefects Rate)}

KPH/PRODUCTION REQUIREMENTS PER YEAR which then calculates the target production needs per week by dividing the production needs per year divided by 52 (because in 1 year there are 52 weeks.

\section{RESULT AND DISCUSSION}

The data that the defect rate is looking for in this study is the work unit for making tables, making front seats, making machine boxes, making rear seats, assembling and automation.

\section{Table 1 Work Unit}

\begin{tabular}{clc}
\hline Station & Work Unit & Defectsrate \\
\hline A & Table Making & $10 \%$ \\
B & $\begin{array}{l}\text { Front Seat } \\
\text { Manufacture }\end{array}$ & $6.6 \%$ \\
C & $\begin{array}{l}\text { Machine Box } \\
\text { Making }\end{array}$ & $3.3 \%$ \\
D & $\begin{array}{l}\text { Rear Seat } \\
\text { Manufacture }\end{array}$ & $3.3 \%$ \\
E & Assembly & $10 \%$ \\
F & Automation & $3.3 \%$ \\
\hline
\end{tabular}

Table. 2 Defect Rate of Table Making

\begin{tabular}{cc}
\hline $\begin{array}{c}\text { Making Table(October) } \\
\text { Week }\end{array}$ & Number ofDefects \\
\hline 1 & 1 \\
2 & 0 \\
3 & 2 \\
4 & 0 \\
\hline
\end{tabular}




\section{Tibuana}

Journal of applied Industrial Engineering-University of PGRI Adi Buana

DOI : https://doi.org/10.36456/tibuana.4.01.3173.23-27

Table 3 Front Seat Defect Rate

\begin{tabular}{cc}
\hline $\begin{array}{c}\text { Front Seat Manufacture (October) } \\
\text { Week }\end{array}$ & \begin{tabular}{c} 
Number of Defects \\
\hline 1
\end{tabular} \\
2 & 0 \\
3 & 0 \\
4 & 1 \\
\hline
\end{tabular}

Table 4. Defect rate of Making Machine Box

\begin{tabular}{cc}
\hline $\begin{array}{c}\text { Machine Box Making(October) } \\
\text { Week }\end{array}$ & Number of Defects \\
\hline 1 & 0 \\
2 & 0 \\
3 & 0 \\
4 & 1 \\
\hline
\end{tabular}

Table 5. Defect rate of making rear seats

\begin{tabular}{cc}
$\begin{array}{c}\text { Rear Seat Manufacture(October) } \\
\text { Week }\end{array}$ & \begin{tabular}{c} 
Number of Defects \\
\hline 1
\end{tabular} \\
2 & 1 \\
3 & 0 \\
4 & 0 \\
\hline
\end{tabular}

Table 6. Defect rate of assembly

\begin{tabular}{lc}
\hline \multicolumn{2}{c}{ Assembly(October) } \\
Week & Number of Defects \\
\hline 1 & 1 \\
2 & 0 \\
3 & 1 \\
4 & 1 \\
\hline
\end{tabular}

Table 7. Defect rate of automation

\begin{tabular}{cc}
\hline $\begin{array}{c}\text { Automation(November) } \\
\text { Week }\end{array}$ & Number of Defects \\
\hline 1 & 0 \\
2 & 1 \\
3 & 0 \\
4 & 0 \\
\hline
\end{tabular}




\section{Tibuana}

Journal of applied Industrial Engineering-University of PGRI Adi Buana

DOI : https://doi.org/10.36456/tibuana.4.01.3173.23-27

Demand

Table 8 Demand for the last 3 years

\begin{tabular}{ccc} 
No & Year & Demand \\
1 & 2015 & 4326 \\
2 & 2016 & 5417 \\
3 & 2017 & 6727 \\
\hline
\end{tabular}

Table 9 Sales Data for the last 3 years

\begin{tabular}{|c|c|c|c|c|}
\hline Year & Period $(t)$ & $\begin{array}{c}\text { Sales } Y(t) \\
\text { (unit) }\end{array}$ & $\operatorname{ty}(\mathrm{t})$ & $t^{2}$ \\
\hline 015 & 1 & 4236 & $42 \delta$ & 1 \\
\hline Diló & $!$ & $5+1 ?$ & 16834 & 4 \\
\hline 017 & 3 & $60 ? 7$ & 20181 & 3 \\
\hline Inmad 2 & 6 & $16+7 ?$ & 33341 & 14 \\
\hline
\end{tabular}

$\mathrm{b}=\frac{(3)(3)-(1 \quad)(6)}{(3)(1)-(3)}$

$=1200,5$

$\mathrm{a}=\frac{1}{3}-\frac{(1,5)(6)}{(3)}$

$=3089$

so, $\mathrm{Y}(\mathrm{t})$ is $3089+(\mathbf{1 2 0 0 , 5})(\mathrm{t})$
Thus the results of forecasting the next 3 years are

$\mathrm{Y}(4)=3089+(1200,5)(4)=7.911$ Unit

$Y(5)=3089+(1200,5)(5)=9.116,5$ Unit

$Y(6)=3089+(1200,5)(6)=10.292$ Unit

Table 10 forecasting the next 3 years

\begin{tabular}{|c|c|}
\hline Year & Forecast \\
\hline 2019 & 7911 \\
\hline 2020 & 9116,5 \\
\hline 2021 & 10,292 \\
\hline
\end{tabular}

Production needs per year

Demand $+\sum$ (DemandxDefects Rate $)$

$=7911+[(10 \% \times 7911)+(6,6 \% \times 7911)$

$+(3,3 \% \times 7911)+(3,3 \% \times 7911)+(10 \%$

$\mathrm{x} 7911)+(3,3 \%$ x 7911)]

$=2887,5$ unit

Assuming 1 year $=52$ weeks, then the production needs per week

$=2887,5: 52$

$=55,52$
$=56$ unit.

\section{CONCLUSION}

Based on the results of research and data taken from the last three years and calculating supply-demand analysis, companies can determine sales targets and forecasts for the next three years, from the amount of production that must be met per year, this figure will help to make a plan for unit production needs the time. After the production time unit number can be determined the production target to be 


\section{Tibuana}

Journal of applied Industrial Engineering-University of PGRI Adi Buana

DOI : https://doi.org/10.36456/tibuana.4.01.3173.23-27

$p$-ISSN 2622-2027

$e$-ISSN 2622-2035

undertaken can be calculated. The production target calculation is carried out over a 3 year planning horizon.

From the calculations above, the results obtained for the production of each migrant are 56 units. This data is obtained from the calculation of the forecast for the next three years.

\section{REFERENCE}

[1] Aryanto, Yunus. 2018. Meja\&Kursi. Depok: GriyaKreasi.

[2] Chen, Chun-Tung., Kuo Hsiang Chen, Min-Yuan Ma.2012. The

Research of the Application of Quality Function Deployment in the Design and Development of ALL-Plastic Folding Chair, Journal of Convergence Information Technology (JCIT)

[3] KamusBesar Bahasa Indonesia. 9 Februari 2017. Lipat.http://kbbi.web.id/lipat

[4] Kusdiah, Yuli., 2013, Aplikasi Metode Quality Function Deployment (QFD) dalam Redesain Kursi Gambar, "ILTEK", Volume 8, Nomor 15

[5] Mulyati. 9 Februari 2017. MacamMacamBahan dan Proses FinishingKayu/Mebel.http://finishingjati.blogspot.co.id/2016/02/macammacam-bahan-finishing-kayu.html

[6] Widodo, 2003, Bioteknologi Industri Susu, Lacticia Press, Yogjakarta

[7] Wignjosoebroto, Sritomo, 2003, Ergonomi Studi Gerak dan Waktu, Cetakan Ketiga, Guna Widya, Jakarta

[8] Wignjosoebroto, Sritomo, 2006, "Pengantar Teknik dan Manajamen Industri", Guna Widya, Surabaya 